19 Revue d'histoire du XIXe siècle

Société d'histoire de la révolution de 1848 et des

révolutions du XIXe siècle

$1 \mid 1985$

Varia

\title{
Un ouvrier en 1820, manuscrit inédit de Jacques Étienne
}

Bédé

édité par Rémi Gossez, avant-propos de Louis Girard, Presses

universitaires de France, 1984, 405 p.

Jean-Yves Mollier

\section{CpenEdition}

Édition électronique

URL : http://journals.openedition.org/rh19/351

DOI : $10.4000 /$ rh 19.351

ISSN : $1777-5329$

Éditeur

La Société de 1848

Édition imprimée

Date de publication : 1 juin 1985

ISSN : 1265-1354

Référence électronique

Jean-Yves Mollier, « Un ouvrier en 1820, manuscrit inédit de Jacques Étienne Bédé », Revue d'histoire du XIXe siècle [En ligne], 1 | 1985, mis en ligne le 28 octobre 2002, consulté le 22 septembre 2020. URL: http://journals.openedition.org/rh19/351 ; DOI : https://doi.org/10.4000/rh19.351

Ce document a été généré automatiquement le 22 septembre 2020

Tous droits réservés 


\section{Un ouvrier en 1820, manuscrit inédit de Jacques Étienne Bédé}

édité par Rémi Gossez, avant-propos de Louis Girard, Presses universitaires de France, 1984, 405 p.

Jean-Yves Mollier 
Commencé en 1820, à Sainte-Pélagie, ce texte vient d'abord combler un vide, celui des mémoires ouvriers avant 1830. "Récit historique des ouvriers tourneurs en chaises", le manuscrit d'Étienne Bédé est le premier document rédigé par un ouvrier, au nom des siens, où s'expriment une vision et une pratique collectives de la liberté du travail décrétée en 1791. Précieusement annoté et savamment introduit par Rémi Gossez, spécialiste de l'organisation et de l'association ouvrières en 1848, ce livre témoigne de l'existence d'un mouvement ouvrier en gestation dans les années post-

révolutionnaires.

La Fabrique parisienne se transforme, la manufacture s'étend, les artisans cèdent la place aux négociants et les ouvriers s'acharnent à défendre leur travail à la tâche, en refusant les corvées et les besognes improductives qui diminuent leur salaire. Les sociétés de secours mutuels organisent les travailleurs et leur donnent conscience de leur force nouvelle.

Observateur lucide, mais prudent, le narrateur évoque son enfance dans la région d'Orléans, la Révolution, Paris en 1793, ses sept années de campagnes militaires dans l'armée du général Moreau, les désertions, le retour au pays et l'installation dans la capitale en 1811. Son amour du métier, son sens de la solidarité se heurtent au développement économique et aux nouveaux rapports de production. Les "nouveaux maîtres", patrons capitalistes acharnés à défendre leur profit au détriment des intérêts des

ouvriers sont la cible du dirigeant pré-syndical que devient Bédé. La grève est leur fait, l'organisation des tourneurs en chaises la conséquence de leur attitude. En marge des luttes politiques de la Restauration, ce conflit du travail, minutieusement décrit, permet de mieux saisir la lente transformation des ouvriers, du compagnonnage au syndicalisme, et la recherche permanente d'une dignité humaine dans l'indépendance et le respect des engagements. 